\title{
Length-weight relationship and reproduction of the guppy Poecilia reticulata (Cyprinodontiformes: Poeciliidae) in urban drainage channels in the Brazilian city of Belém
}

\author{
Luciano Fogaça de Assis Montag, ${ }^{1,3}$ Tiago Magalhães da Silva Freitas², \\ Roberta Dannyele de Oliveira Raiol ${ }^{1}$ \& Marlene Vasconcelos da Silva ${ }^{1}$ \\ ${ }^{1}$ Laboratório de Ecologia e Zoologia de Vertebrados, Instituto de Ciências Biológicas, \\ Universidade Federal do Pará-UFPA, Rua Augusto Corrêa, 01, Guamá, CP 479, CEP 66075-110, Belém, \\ PA, Brazil \\ ${ }^{2}$ Faculdade de Ciências Naturais, Universidade Federal do Pará - UFPA, \\ Campus Universitário do Marajó, Conjunto Bandeirante, Aeroporto, CEP 68800-000, Breves, PA, Brazil \\ ${ }^{3}$ Corresponding author: Luciano Fogaça de Assis Montag, e-mail: montag@ufpa.br
}

MONTAG, L.F.A., FREITAS, T.M.S., RAIOL, D.O. \& SILVA, M.V. Length-weight relationship and reproduction of the guppy Poecilia reticulata (Cyprinodontiformes: Poeciliidae) in urban drainage channels in the Brazilian city of Belém. Biota Neotrop. 11(3): http://www.biotaneotropica.org.br/v11n3/en/ abstract?article+bn01811032011

\begin{abstract}
This paper describes the length-weight relationship, size at first maturation (L), and breeding season of Poecilia reticulata found in drainage channels on the campus of the Federal University of Pará (UFPA) in the Brazilian city of Belém. A total of 1.936 specimens (942 males and 994 females) were collected in monthly samples of the study area between June, 2006, and March, 2007. Females were significantly longer and heavier than males. The length-weight relationship for males was established by the equation $\mathrm{Pt}=5 \times 10^{-5} \times \mathrm{Ct}^{2.397}$ and for females by $\mathrm{Pt}=3 \times 10^{-6} \times \mathrm{Ct}^{3.419}$. The estimated value of $\mathrm{L}$ was $17.5 \mathrm{~mm}$ for males and $20.4 \mathrm{~mm}$ for females, suggesting that males initiate reproductive activity at a smaller size than females. The abundance of mature females did not vary significantly among months, and there was little variation in the sex ratio, which was close to parity overall. Despite the adverse conditions encountered in the UFPA drainage system, $P$. reticulata appeared to have adapted its biological processes adequately.
\end{abstract}

Keywords: fish ecology, urban environments, breeding, amazon, poecilia reticulata.

MONTAG, L.F.A., FREITAS, T.M.S., RAIOL, D.O. \& SILVA, M.V. Relação peso-comprimento e reprodução do guppy Poecilia reticulata (Cyprinodontiformes: Poeciliidae) em canais de coleta residual na região metropolitana de Belém, Pará, Brasil. Biota Neotrop. 11(3): http://www.biotaneotropica.org.br/v11n3/pt/ abstract?article+bn01811032011

Resumo: O presente trabalho tem por objetivo descrever aspectos populacionais relacionados ao estabelecimento da relação peso/comprimento, estimativa de tamanho de primeira maturação (L) e período reprodutivo de Poecilia reticulata encontrados em sistemas de coleta residual no campus da Universidade Federal do Pará, região metropolitana de Belém - PA (Brasil). Foram realizadas coletas mensais no período de junho de 2006 a março de 2007, utilizando um puçá, que resultou na captura de 1.936 exemplares, sendo 942 machos e 994 fêmeas. As fêmeas apresentaram-se maiores e mais pesadas que os machos. A relação peso/comprimento para machos foi estabelecida pela equação $\mathrm{Pt}=5 \times 10^{-5} \times \mathrm{Ct}^{2,397}$ e para fêmeas esta foi dada pela fórmula $\mathrm{Pt}=3 \times 10^{-6} \times \mathrm{Ct}^{3,419}$. Os valores estimados para L foi 17,5 $\mathrm{mm}$ para machos 20,4 $\mathrm{mm}$ para fêmeas, sugerindo que os machos iniciam atividades reprodutivas em tamanhos menores que as fêmeas. A frequência mensal de fêmeas maduras não variou significativamente. Além disso, também não foram encontradas diferenças na proporção sexual durante os períodos investigados, sendo no geral, a proporção de fêmeas iguais as de machos. Desta forma, verificamos que, apesar das condições presentes nos sistemas de coleta residual da UFPA, a espécie $P$. reticulata parece ter adaptado seus processos biológicos.

Palavras-chave: autoecologia de peixes, ambientes urbanos, reprodução, amazônia, poecilia reticulata. 


\section{Introduction}

The poeciliids, commonly known as guppies, are fish of the order Cyprinodontiformes with an ample distribution, principally in the watercourses of southern and central America (Lucinda 2003, Nelson 2006, Araújo et al. 2007). Guppies have also been introduced into the wild in many regions worldwide as a biological agent for the control of mosquito larvae (Lucinda 2003) and are popular ornamental fish.

Poecilids are able to both inhabit a wide diversity of environments and tolerate high levels of habitat disturbance, being able to survive in environments that many other species are unable to endure (Araújo et al. 2003). These ecological characteristics appear to be related to the dietary flexibility of the guppies, and the fact that they do not require sites with specific characteristics for breeding (Reznick \& Bryga 1996).

Many species of this family, principally Poecilia reticulata Peters, 1859 and Phalloceros caudimaculatus (Hensel 1868), are used as indicator species for the evaluation of the integrity of aquatic habitats (Bozzetti \& Schulz 2004, Ferreira \& Casatti 2006, Pinto et al. 2006, Vieira \& Shibatta, 2007). Despite this interest in the group, there have been few studies of Brazilian populations, especially in the Amazon region, and few data are available on patterns of reproduction and growth in the poeciliids of this region. The principal population studies have all been conducted in southeastern Brazil - Aranha \& Caramaschi (1999), analyzed the population structure of a cyprinodontiform community, while Machado et al. (2002) studied the reproductive cycle of $P$. caudimaculatus, and Araújo et al. (2007) focused on the distribution pattern of poeciliids in polluted streams.

In most major urban centers, the disposal of large quantities of chemical and industrial waste into drainage systems has negative effects on local water quality and aquatic habitats (Paranhos et al. 2006), provoking modifications in the breeding patterns and growth rates of the fish species that inhabit urban environments (Martin-Smith 1998, Cunico et al. 2006). Given this potential problem, the present study analyzed on a population of guppies, Poecilia reticulata (Cyprinodontiformes: Poeciliidae), inhabiting an open-air drainage system in the metropolitan area of the Brazilian city of Belém (the main campus of the Federal University of Pará). The analyses were based on the establishment of the length-weight formula, size at first maturation (L) and the breeding season.

\section{Methods}

\section{Study area}

The study focused on the open-air drainage system of the main campus of the Federal University of Pará (UFPA), located in the metropolitan area of Belém, the capital of the Brazilian state of Pará (Figure 1). The specific site was the system of concrete channels adjacent to the Institute of Biological Sciences (IBC; $1^{\circ} 28^{\prime} 24.9$ ' S, $48^{\circ} 27^{\prime} 26.0^{\prime \prime} \mathrm{W}$ ), which are approximately $50 \mathrm{~cm}$ in depth, and receive a constant influx of chemical residues from the IBC laboratories, as well as the tidal waters of the Guamá River, which borders the campus. In addition to Poecilia reticulata, a second cyprinodontiform species, the exotic poeciliid Xiphophorus hellerii Heckel, 1848 can be found in the channels, as well as Synbranchus marmoratus Bloch, 1795 (Synbranchiformes: Synbranchidae).

\section{Data collection}

Specimens of $P$. reticulata were collected in the three channels adjacent to the IBC on a monthly basis between June, 2006, and March, 2007, using a hand-net with a $32 \mathrm{~cm} \times 23 \mathrm{~cm}$ rim and $1 \mathrm{~mm}$

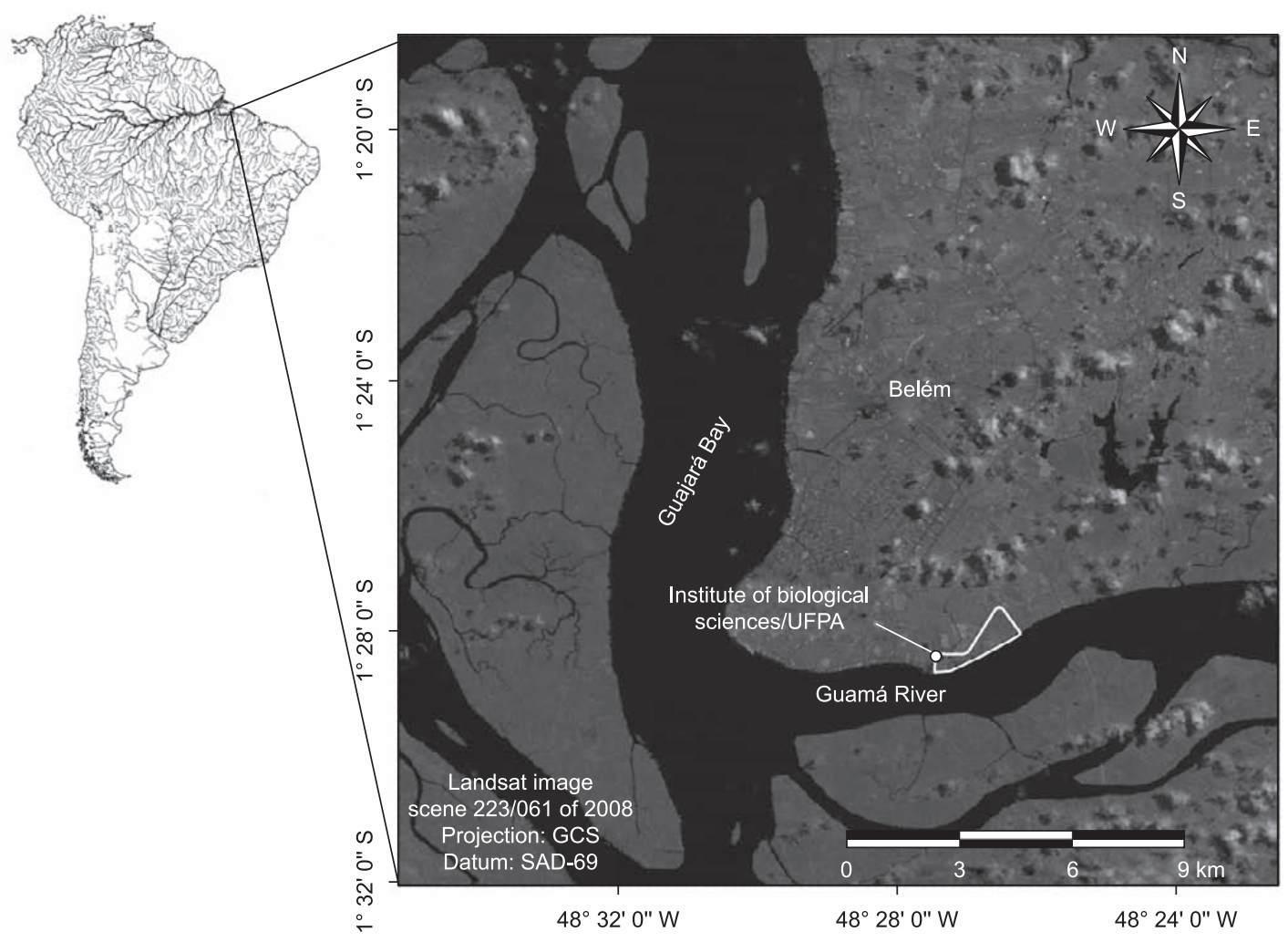

Figure 1. Location of the UFPA Biological Sciences Institute in the Brazilian city of Belém, where the specimens of $P$. reticulata were captured between June, 2006, and March, 2007.

Figura 1. Localização do Instituto de Ciências Biológicas (Belém - Pará) onde espécimes de P. reticulata foram coletados entre junho de 2006 a março de 2007. 
mesh. While the original aim of the study was to cover a full annual cycle, the study area was dredged clean following the tenth month of sampling, impeding the collection of additional specimens.

The specimens of $P$. reticulata collected during sampling were measured (total length, Lt, in $\mathrm{mm}$ ) and weighed (total weight, $\mathrm{Wt}$, in $\mathrm{g}$ ), sexed, and classified according to their sexual maturity (reproductive or non-reproductive). This classification was used to estimate body size at first gonadal maturity. The specimens were examined using a stereomicroscope, and males were considered sexually mature when they presented a completely-formed gonopod, while females were classified as mature when their gonads containing oocytes/eggs or embryos (Vazzoler 1996). All the specimens were fixed in $10 \%$ formaldehyde and conserved in $70 \%$ ethanol before being deposited in the ichthyological collection of the Goeldi Museum in Belém, under the catalog numbers MPEG 13410-13417.

\section{Data analysis}

The statistical significance of the sexual dimorphism (body weight and length) of $P$. reticulata was evaluated using the $t$ test, given the satisfaction of the assumptions of data normality and homoscedasticity. The length-weight formula for each sex was found by adjusting Huxley's (1924) allometric equation $y=a \cdot x^{b}$, using the Solver routine available in Microsoft Excel ${ }^{\circledR}$ 2007. This equation assumes that bodily dimensions increase by a constant (b), which is known as the coefficient of allometry. The values of b may be interpreted in the following manner (Huxley 1924) - when the bodily dimensions (length and weight in this case) vary proportionately, i.e., isometrically, $\mathrm{b}$ is equal to 3 . When body size increases at a faster rate than weight $(b<3)$, there is negative allometry, while positive allometry occurs when weight increases at a faster rate than body size $(b>3)$. As one of the objectives of the study was the identification of possible differences in growth patterns between the sexes, a single weight-length function was initially adjusted to the sample as a whole, and the residual values for males and females were compared using a $t$ test.

Body size at first sexual maturation (L) was estimated separately for the two sexes, with the males being arranged in length classes of $0.5 \mathrm{~mm}$, and the females in classes of $1.0 \mathrm{~mm}$. The estimate was based on Trippel \& Harvey's (1991) logistic equation: $P=A /\left(1+e^{(r .(L t-L 50))}\right.$, where $\mathrm{P}=$ the proportion of reproductive adults in each size class, $\mathrm{A}=$ the asymptote of the curve $(A=1), r=$ the rate of change between non- and reproductive individuals, $\mathrm{Lt}=$ the total length $(\mathrm{cm})$ used in the size classes, and $\mathrm{L}=$ the size $(\mathrm{cm})$ at which $50 \%$ of the individuals reaches sexual maturity. The parameters of this equation were also adjusted using the Solver routine in Microsoft Excel.

The definition of the breeding season was based on the analysis of the relative frequency of mature females recorded each month over the study period, adjusted using a sinusoidal function, as proposed by Fontoura \& Agostinho (1996). This procedure describes seasonal variation based on the formula: $F M F=M+A * \cos (2 \pi /(F r q *(t-f)))$, where $\mathrm{FMF}=$ Frequency of Mature Females, $\mathrm{M}=$ the mean number of mature females recorded per month over the study period, $\mathrm{A}=$ the amplitude of the monthly variation in the number of mature females (difference between the overall mean and the mean of the maximum and/or minimum values), Frq = units of time in which the events were measured (here, Frq $=12$ when the measured time is month), $\mathrm{t}=$ numerical scale of time (here, January $=1$, February $=2$, March $=3 \ldots$ December $=12$ ), and $\mathrm{f}=$ the difference between the baseline time and the time with the maximum frequency of mature females (representing the sinusoid). The impossibility to complete an annual cycle did not interfered the sinusoidal analysis.

The coefficients of determination $\left(\mathrm{R}^{2}\right)$ and respective $\mathrm{p}$ values were also obtained for both $\mathrm{L}$ and the sinusoidal equation. The values of $\mathrm{R}^{2}$ were calculated by the ratio of the sum of the squares of the residuals to the total sum of squares, with the $\mathrm{p}$ values being obtained through a significance test based on the F statistic, with a 5\% significance level (Zar 2010). The deviation of the sex ratio from parity during the study period was also tested using Chi-square, also with $\alpha=0.05$.

\section{Results}

A total of 1936 specimens of $P$. reticulata were collected during the study period (June, 2006, to March, 2007), of which 942 were males, and 994, females. There was significant sexual dimorphism in terms of both body weight and length ( $p=0.000$ in both cases), with females being larger than males, on average. Mean body weight in females was $0.13 \pm 0.1 \mathrm{~g}$ (range: $0.02-0.46 \mathrm{~g}$ ) in comparison with $0.07 \pm 0.1 \mathrm{~g}(0.03-0.12 \mathrm{~g})$ in males, while mean body length was $22.7 \pm 5.0 \mathrm{~mm}$ (range: $13.1-35.1 \mathrm{~mm}$ ) in females and $20.1 \pm 1.5 \mathrm{~mm}$ (range: $16.0-23.9 \mathrm{~mm}$ ) in males.

The comparison of the residues of the combined length-weight relationship for males and females indicated a significant difference in growth patterns between the sexes $(t=-10.01$, d.f. $=1935, \mathrm{p}=0.000)$, which clarified the need for the application of distinct equations for males and females. In the males, the length-weight relationship was established through the equation $\mathrm{Pt}=5 \times 10^{-5} \times \mathrm{Ct}^{2.397}\left(\mathrm{R}^{2}=0.68\right.$; Figure 2a), while for the females, the formula was $\mathrm{Pt}=3 \times 10^{-6} \times$ $\mathrm{Ct}^{3.419}\left(\mathrm{R}^{2}=0.97\right)$ (Figure 2b). Whereas the growth pattern of the males was negatively allometric $(b=2.397)$, i.e., the increase in body size was disproportionately greater than that in weight, the females
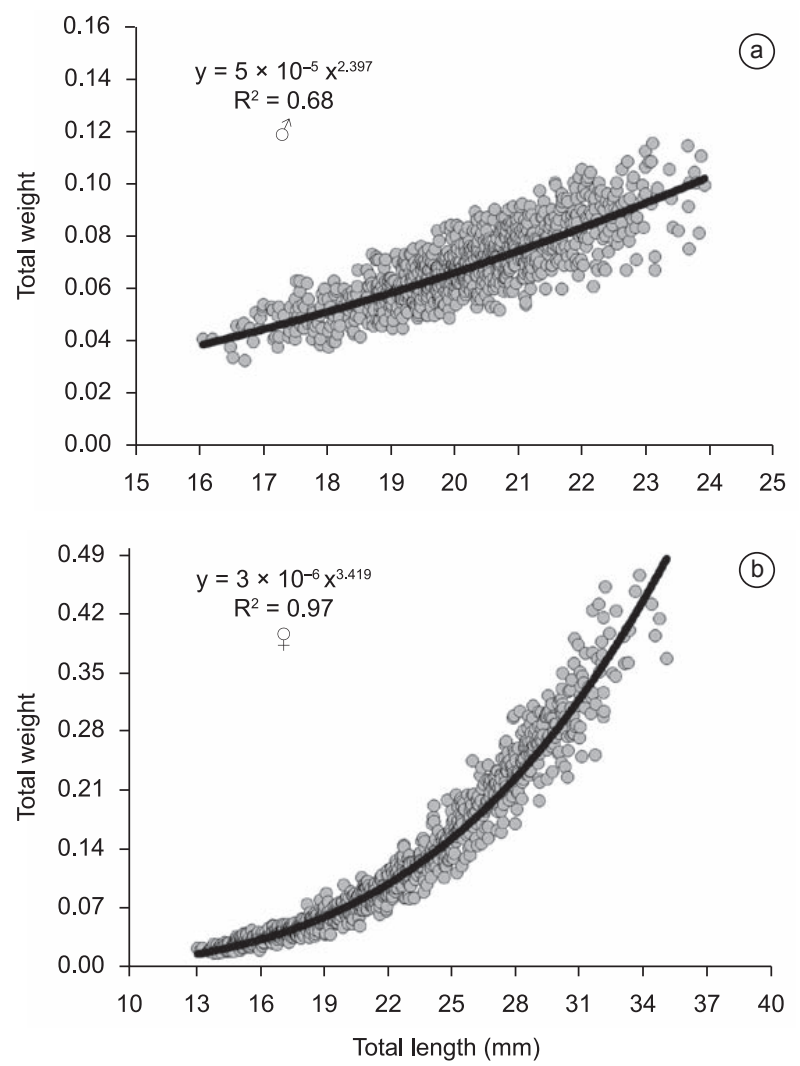

Figure 2. Length-weight relationship in the male a) and female b) of $P$. reticulata collected in the drainage system of the IBC on the UFPA campus in the metropolitan area of the Brazilian city of Belém.

Figura 2. Relação peso-comprimento para machos a) e fêmeas b) de $P$. reticulata dos sistemas de coleta residuais no campus da UFPA, na região metropolitana de Belém - PA. 
presented positive allometry $(b=3.419)$, with the gain in weight outpacing that of body size.

Estimated size at first maturity (L) was $17.5 \mathrm{~mm}$ for males $\left(\mathrm{R}^{2}=0.942, \mathrm{~F}=87.09, \mathrm{p}=0.002\right.$ ) (Figure 3a) and $20.4 \mathrm{~mm}$ for females $\left(\mathrm{R}^{2}=0.999, \mathrm{~F}=7976.4, \mathrm{p}=0.000\right)$ (Figure 3b), indicating that the males engage in reproductive behavior at a smaller size than the females. The size classes smaller than $17 \mathrm{~mm}$ and larger than $24 \mathrm{~mm}$ were excluded from the analysis of the males due to the small numbers of specimens involved. Similarly, the female specimens with size below $13.5 \mathrm{~mm}$ and above $32.5 \mathrm{~mm}$ were also excluded from the analysis.

The sinusoidal equation did not describe any clear seasonal pattern in the monthly frequency of mature female $P$. reticulata in the drainage channels of the UFPA campus $\left(\mathrm{R}^{2}=0.65, \mathrm{~F}=3.29\right.$, $\mathrm{p}=0.133$ ) (Figure 4). On average, approximately $60 \%$ of the females captured each month were sexually mature. In addition, no significant variation was found in the sex ratio during the study period, with the overall proportion of females almost equal to that of males $\left(\chi^{2}=1.40\right.$, d.f. $\left.=1, p=0.246\right)$.

\section{Discussion}

The female-biased sexual dimorphism recorded in the present study for $P$. reticulata is similar to that observed in the same species by Sterba (1983) and Hernández et al. (2004), who recorded maximum body lengths of $60 \mathrm{~mm}$ and $51.1 \mathrm{~mm}$, respectively, for females, in
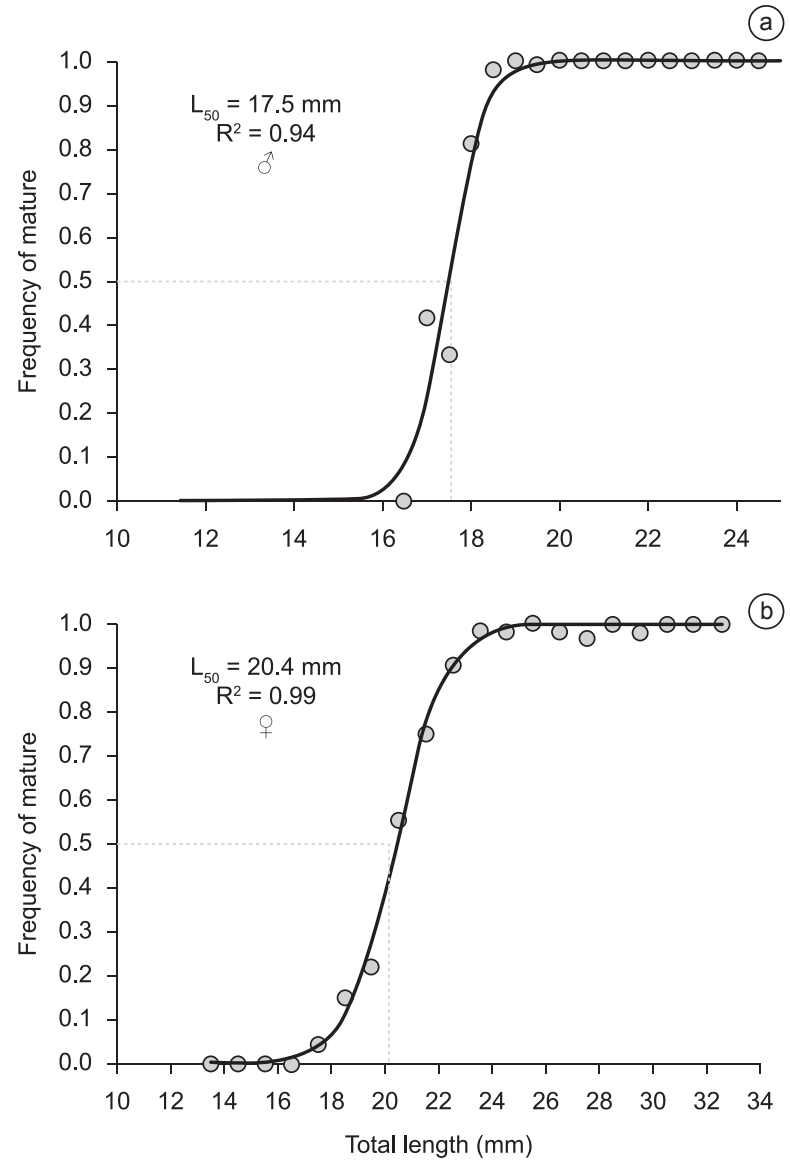

Figure 3. Estimating size at first maturity of male a) and female b) of $P$. reticulata through the frequency of mature fish against the total length.

Figura 3. Frequência de indivíduos maduros pelo comprimento total na estimativa de tamanho de primeira maturação sexual $(\mathrm{L} ; \mathrm{mm})$ para machos a) e fêmeas b) de Poecilia reticulata. comparison with values of approximately $30 \mathrm{~mm}$ in males. While the degree of dimorphism is similar, the maximum values recorded in the present study were well below those reported by these authors, which may be related to differences in the quality of the habitats occupied by the different populations (Lizama \& Takemoto 2000). However, despite the number of habitats impacted by urbanization, relatively few studies have focused on the reproductive parameters of fish populations in polluted environments (Becker et al. 2010).

The larger size of the females is an expected trait of viviparous species, in which fecundity is directly related to body size (Batista 1991), and the females invest more energy in their development than the males, a common pattern in the poeciliids (Machado et al. 2002). This accounts for the positive allometry recorded in the females $(b \approx 3.4)$, reflecting a strategy aimed at maximizing reproductive output, in which the females accumulate as much energy as possible for their gonadal production (Keane \& Neira 2004, Wolf et al. 2007).

By contrast, the males require more energy for courtship and mating with viable partners, as well as the need to invest in the production of secondary sexual characteristics, such as the elaborate caudal fin typical of the species, which may explain the negative allometry $(b \approx 2.4)$ recorded in this study. As mentioned above, this pattern of growth involves disproportionate growth of body size over weight, and may reflect the need to grow rapidly in order to compete for reproductive opportunities and guarantee the transmission of their genes (Vazzoler 1996).

In addition to the growth pattern, the values estimated for size at first maturity (L) in P. reticulata were also differentiated by sex, with the females reaching sexual maturity at a larger size than males. These findings are in accordance with the conclusions of Vargas \& Sostoa (1996), who recorded marked sexual dimorphism in body size in many species of the Poecilidae, including $P$. reticulata, with the males being reproductively more precocious in comparison with the females.

However, the parity of the sex ratio recorded in the present study contrasts considerably with the female-biased ratio (4:1) recorded by Valério \& Súarez (2005). Nikolsky (1963) confirmed that the sex ratio may vary not only between populations of the same species, but also in the same population during different periods, presumably in order to guarantee a predominance of females when conditions are

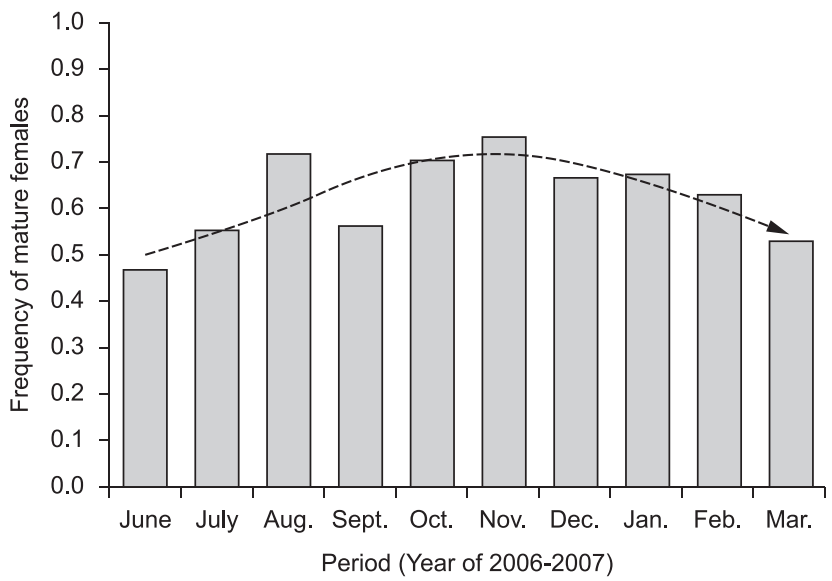

Figure 4. Monthly variation in the number of mature female $P$. reticulata captured in the drainage channels of the UFPA campus in Belém. The dotted line indicates the values estimated for each month using the sinusoidal equation.

Figura 4. Variação mensal de fêmeas maduras de $P$. reticulata nos canais de coleta residual do campus da UFPA; a linha tracejada indica os valores estimados, por mês de coleta, obtidos pela equação senóide. 
most favorable for reproduction, such as during the colonization of a new habitat.

Overall, then, clear differences were recorded between the sexes in $P$. reticulata in all the parameters analyzed, ranging from the length-weight relationship to growth rates and size at first maturity (L). Despite the relatively poor quality of the environment inhabited by the population, the species appears to have adapted its biological processes to the prevailing conditions, in particular by limiting growth and maturing at smaller body sizes.

\section{Acknowledgements}

We are grateful to the Brazilian National Research Council $(\mathrm{CNPq})$ for providing masters and undergraduate stipends, and to the Ichthyology Sector of the Museu Paraense Emílio Goeldi (MPEG) in Belém for providing essential infrastructure for the development of this study.

\section{References}

ARANHA, J.M.R. \& CARAMASCHI, E.P. 1999. Estrutura populacional, aspectos da reprodução e alimentação dos Cyprinodontiformes (Osteichthyes) de um riacho do sudeste do Brasil. Rev. Bras. Zool. 16(1):637-651.

ARAÚJO, F.G., FICHBERG, I., PINTO, B.C.T. \& PEIXOTO, M.G. 2003. A preliminary index of biotic integrity for monitoring the condition of the rio Paraíba do Sul, Southeast Brazil. Environ. Manage. 32(4):516-526.

ARAUJO, F.G., PEIXOTO, M.G., PINTO, B.C.T. \& TEIXEIRA, T.P. 2007. Distribution of guppies Poecilia reticulata (Peters, 1860) and Phalloceros caudimaculatus (Hensel, 1868) along a polluted stretch of the Paraíba do Sul River, Brazil. Braz. J. Biol. 69(1):41-48.

BATISTA, V.S. 1991. Aspectos quantitativos da fecundidade e do desenvolvimento embrionário da raia Zapteryx brevirostris Müller \& Henle, 1841 (Pisces, Rhinobatidae) da Enseada de Itaipu, Niterói, Rio de Janeiro. Rev. Bras. Biol. 51(3):495-501.

BECKER, F.G., FRIES, L.C.C., GUIMARÃES, T.F.R. \& MENESES, B.A 2010. Pesquisa sobre reprodução de populações naturais de peixes no Brasil (2001-2010):um breve panorama sobre tendências e lacunas. Bol. Soc. Bras. Ictiol. 100:40-44.

BOZZETTI, M. \& SCHULZ, U.H. 2004. An index of biotic integrity based on fish assemblages for subtropical streams in southern Brazil. Hydrobiologia 529:133-144. http://dx.doi.org/10.1007/s10750-004-5738-6

CUNICO, A.M., AGOSSTINHO, A.A. \& LATINI, J.D. 2006. Influência da urbanização sobre as assembléias de peixes em três córregos de Maringá, Paraná. Rev. Bras. Zool. 23(4):1101-1110. http://dx.doi.org/10.1007/ s10750-004-5738-6

FERREIRA, C.P. \& CASATTI, L. 2006. Influência da estrutura do hábitat sobre a ictiofauna de um riacho em uma micro-bacia de pastagem, São Paulo, Brasil. Rev. Bras. Zool. 23(3):642-651. http://dx.doi. org/10.1590/S0101-81752006000300006

FONTOURA, N.F. \& AGOSTINHO, A.A. 1996. Growth with seasonally varying temperatures: an expansion of the von Bertalanfy growth model. J. Fish Biol. 48:569-584. http://dx.doi.org/10.1111/j.1095-8649.1996. tb01453.x

HERNÁNDEZ, M., PEÑA, J.C. \& QUESADA, M. P. 2004. Fecundidad, fertilidad e índice gonadosomático de Poecilia reticulata (Pisces: Poeciliidae) en um estanque en Santo Domingo, Heredia, Costa Rica. Rev. Biol. Trop. 52(4):945-950.
HUXLEY, J.S. 1924. Constant differential growth-ratios and their significance. Nature 14:896-897.

KEANE, J.P. \& NEIRA, F.J. 2004. First Record of mosquitofish, Gambusia affini, in Tasmania, Australia: stock structure and reproductive biology. New Zeal J. Mar. Fresh. 38:852-867. http://dx.doi.org/10.108 0/00288330.2004.9517285 http://dx.doi.org/10.1080/00288330.2004. 9517285

LIZAMA, M.A.P. \& TAKEMOTO, R.M. 2000. Relação entre o padrão de crescimento em peixes e as diferentes categorias tróficas: uma hipótese a ser testada. Acta Sci. 22(2):455-463.

LUCINDA, P.H.F. 2003. Family Poeciliidae. In Check List of the Freshwater Fishes of South and Central America (R.E. Reis; S.O. Kullander \& C.J. Ferraris-Junior. eds.). Edipucrs, Porto Alegre, 712p.

MACHADO, G., GUIARETTA, A.A. \& FACURE, K.G. 2002. Reproductive cycle of a populations of the guary, Phalloceros caudimaculatus (Poeciliidae) in Southeastern Brazil. Stud. Neotrop. Fauna E. 37(1):15-18. http://dx.doi.org/10.1076/snfe.37.1.15.2115

MARTIN-SMITH, K.M. 1998. Relationships between fishes and habitat in rainforest streams in Sabah, Malaysia. J. Fish Biol. 52:458-482.

NELSON, J.S. 2006. Fishes of the world. John Wiley \& Sons, New York, $601 \mathrm{p}$.

NIKOLSKY, G.V. 1963. The ecology of fishes. Academic, Nova York, 352p.

PARANHOS, K.M., 2006. Estimativas populacionais para espécies raras: Mico-leão-preto Leontopithecus chrysopygus (Mikan, 1823) como modelo. Dissertação de Mestrado, Universidade Federal do Paraná, Cutiriba, 62p.

PINTO, B.C.T.; ARAÚJO, F.G. \& HUGHES, R.M. 2006. Effects of landscape and riparian condition on a fish index of biotic integrity in a large southeastern Brazil river. Hydrobiologia 556:69-83. http://dx.doi. org/10.1007/s10750-005-9009-y

REZNICK, D.N. \& BRYGA, H.A. 1996. Life-history evolution in guppies (Poecilia reticulata: Poeciliidae). V. Genetic basis of parallelism in life histories. Am. Nat. 147:339-359. http://dx.doi.org/10.1086/285855

STERBA, G. 1983. The Aquarium Encyclopedia. Mills, New York, 608p.

TRIPPEL, E.A. \& HARVEY, H.H., 1991. Comparison of methods used to estimate age and length of fishes at sexual maturity using populations of white sucker (Catostomus commersoni). Can. J. Fish. Aquat. Sci. 48:1446-1495. http://dx.doi.org/10.1139/f91-172

VALÉRIO, S.B. \& SÚAREZ, Y.R. 2005. Aspectos populacionais de Poecilia reticulata (PETERS, 1859) em um riacho da bacia do rio Dourados-MS. In 57 Reunião Anual da Sociedade Brasileira para o Progresso da Ciência - SBPC. SBPC, Fortaleza.

VARGAS, M.J. \& De SOSTO, A.A. 1996. Life history of Gambusia holbrooki (Pisces, Poeciliidae) in the Ebro delta (NE Iberian Peninsula). Hydrobiology 341:215-224. http://dx.doi.org/10.1007/BF00014686

VAZZOLER, A.E.A., 1996. Biologia da reprodução de peixes teleósteos: teoria e prática. Editora da Universidade Estadual da Maringá, Marigá, 169 p.

VIEIRA, D.B. \& SHIBATTA, O.A. 2007. Peixes como indicadores da qualidade ambiental do ribeirão Esperança, município de Londrina, Paraná, Brasil. Biota Neotrop. 7(1):57-65.

WOLF, L.L., HRECIUK, E.R., VIANA, D., ZALESKI, T. \& DONATTI, L. 2007. Population structure of Phalloceros caudimaculatus (Hensel, 1868) (Cyprinodontiformes, Poeciliidae) collected on a brook in Guarapuava, PR. Braz. Arch. Biol. Techn. 50(3):417-423. http://dx.doi.org/10.1590/ S1516-89132007000300008

ZAR, J.H. 2010. Biostatistical Analysis. 5nd ed. New Jersey, Prentice-Hall, $944 \mathrm{p}$. 